\title{
The Usefulness of the Popular Social Interactive Media in the Classroom
}

\author{
Sofowora, Olaniyi Alaba ${ }^{1, *}$ \\ ${ }^{1}$ Department of Educational Technology, Faculty of Education, Obafemi Awolowo University, Ile-Ife, Nigeria \\ *Correspondence: Department of Educational Technology, Faculty of Education, Obafemi Awolowo University, \\ Ile-Ife, Nigeria $\quad$ Tel: 234-807-822-5786 E-mail: oasofowora@yahoo.com
}

Received: July 6, 2012

Accepted: August 5, $2012 \quad$ Online Published: January 29, 2013

doi:10.5430/wje.v3n1p46

URL: http://dx.doi.org/10.5430/wje.v3n1p46

\begin{abstract}
The paper is an investigation into the possibility of using the popular social interactive media in the classroom in the developing world. There has been different school of thoughts about the usefulness of the interactive social media. The question being widely asked today is, can these popular social media be used constructively in the classroom. This study is therefore designed to provide empirical answer to the above widely asked question. The study employed descriptive survey design. A sample of 500 participants was selected using stratified sampling technique. A questionnaire tagged "PUSIM" was used to collect data for the study. It was tested for internal consistency and a reliability of 0.73 was obtained. Data was analyzed using descriptive and inferential statistics. The results showed that the perceived benefits included flexibility, mobility of students and enhanced communication .It was also an effective and innovative way of presenting subject matters. Succinctly put, social interactive technologies were effective in changing the image of schools, hence its effectiveness in the classroom to enhance flexible, creative and interactive learning.
\end{abstract}

Keywords: emerging technologies; interpretive transformation; reflexive adaptation; social interaction; net working

\section{Introduction}

There has been call for change in the image of schools; this is to ensure that its graduates are able to successfully meet the cultural, economic, scientific and technological challenges of the $21^{\text {st }}$ Century. It also calls for change in the concept of knowledge, teaching/learning processes and skills development. It therefore implies that there must be a change in the teaching and learning processes that are currently prevalent in our schools.Zohar (2011) stresses the need for today graduates to develop high ordered thinking skills, ability for independent learning and to make judgement. It is also expected of them to develop skill for creative and critical thinking. The need for Education for All by the year 2015 also necessitated a change (FME, MDGs 2006). Further argument in support of the change in the image of schools is found in recent educational theories that claim that meaningful knowledge and learning can only be archived through effective participation.

The above change in the school image can be achieved through the "Social Interactive Technologies". There are different terminologies for the social media, some call it, popular social network, and popular interactive technologies while others call it the Emerging Technologies. Commenting on the different terminologies Guri -Rosenblit (2008) says that these new technologies are quite complex in nature and serve a wide variety of functions. To her, they can be used in many rich ways. She is therefore of the opinion that the term is suffering from the "Tower of Babel Syndrome" a confusing language and misleading conclusion, resulting from the fact that people refer to totally different roles while using the same generic terms. Quoting Donohure \& Steiger (2005), Guri-Rosenblit says "the multiple terms reflect the lack of standardized language in the discourse of the role these technologies play in different settings as well as portray different foci in relation to their impact".

Therefore according to Guri- Rosenblit, (2007), the different terms describing the new technologies in literature and in educational settings are a reflection of the ambiguity of their roles and functions. For example one may emphasize the interactivity or the communication functions while another highlights the social or the information retrieval possibilities from a wide range of remote data sources. Zemsky and Massey (2004a) are of the opinion that the lack 
of clarity as to the meaning attached to the new technologies is causing frequent misunderstanding and controversies. One of the controversies generated is the question of whether these emerging technologies can be used constructively in the classroom. Some schools of thought are of the view that under this dispensation the emerging technologies are very effective in the transfer and assimilation of information and also in the creation, sharing and mastery of knowledge. While others argued that there should be shift from transfer and assimilation to creation, mastery and sharing. However, no genuine answers have been provided to the widely question being asked about the effectiveness of popular social network in the classroom. Although there are many research studies on the widespread possibilities of the emerging technologies in some fields, however there are paucity/isolated information about its usefulness in the classroom and for education. This study is therefore designed to investigate the perceived usefulness of the popular social media in the classroom in the developing countries under the depressed economy.

\section{Literature Review}

Nigeria as a developing country is faced with many challenges. Higher education is characterized by inadequate facilities and infrastructures. There is lack of access to quality education; the system is also experiencing poor funding and shortage of academic staff. The above pose a serious threat to the number of qualified candidates that can be admitted into universities in the country. Statistics have it that of the 800,000 students seeking admission into universities only $20 \%$ can be admitted due to lack of facilities. According to This Day Newspaper of April $17^{\text {th }}, 2006$, in $2003 / 2004$ academic session only $24 \%$ of the students that applied for admission could be admitted. The situation was worse in 2005/2006 when only $17 \%$ got admitted. In 2006/2007 academic session it dropped to $8 \%$. By year $2008 / 2009$, the number of admitted student rose slightly to $31 \%$.

It is of the opinion that Nigeria should learn from other developed countries. Cohen (1996) says educational system can benefit from other countries by learning from their success and failure of attempted innovations. The author of this research therefore shares the view of Cohen that we in Nigeria should have a deep understanding about the specific evidence and interpretive transformation in educational selling of countries like Israel, United State of America, Japan, China and India. This is necessary to foster the adoption of educational innovations particularly in this age of globalization and technological break through. This is so because many of these countries have successfully used the emerging technologies in Education. According to the President Advisory Committee on Science and Technology (1997), the new interactive media can facilitate scalable and sustainable educational reforms.

However a note of caution was sounded; when the committee said, implementation of such innovation should not be blindly adopted by others but they should look for a reflective adaptation that will enable the group improve on the innovation. This is why Guri- Rosenblit (2010) advocates for gradual and moderate implementation. Since the new interactive media are widely accepted and popularly used by the Nigerian youths; the author of this study intends to investigate how the Nigerian students have been using the popular interactive social media. It is also designed to provide answer to the question: can these media be effectively used in the classroom?. In order to effectively do these, the following questions were raised.

\section{Research Questions}

Empirical answers will be provided for these questions:

(a) how important are the popular social interactive media to the Nigerian Youths?

(b) to what extent are the popular social interactive media being used in the class rooms in Nigeria?

(c) are these popular media effective?

(d) why do they think they are effective in the classroom?, and

(e) what are the perceived benefits/ usefulness of these social interactive media to students? In order to answer these questions, the following research objectives are generated.

\section{Research Objectives}

(a) investigate the perceived importance of the social interactive media across different subject groups among the students, 
(b) determine the extent of utilization of the social interactive media in education across different subject groups,

(c) find out if these social interactive media are effective in education across the different subject groups,

(d) investigate the perceived usefulness/benefits across the different subject groups.

\section{Research Hypotheses}

i. There is no difference in the level of perceived importance of the popular interactive social media among the students across the different subject groups.

ii. There is no significant difference in the extent of utilizing the popular interactive social media across the different subect groups.

iii. Students across the different subject groups perceived popular intereactive social media as ineffective in education.

iv. There is no difference in the perceived usefulness of the popular interactive socia media across the different suject groups

\section{Methodology}

This study employed the descriptive survey design.

(a) Population /Sample

The study population is made up of all students of Obafemi Awolowo University, Ile-Ife in Osun State, Nigeria. Out of which five hundred and fifty students across five faculties were selected using stratified sampling technique based on subject area, level of study and sex.

(b) Research Instrument

A questionnaire on the perceived usefulness of the social interactive media in the classroom [PUSIM] was developed and used for data collection. The PUSIM was divided into sections containing fifty items. It was designed to answer the research questions and is developed based on relevant literature and the research objectives.Section 1 asked for information on the demographic status of the sample while section II was on the perceived importance of the social interactive media. Section III was on the extent of its utilization in the classroom. Sections IV and V respectively measured the degree of usefulness and why they consider them of benefits in the classroom across the different subject groups. The questionnaire was tested for internal consistency reliability and a reliability of 0.73 was obtained using two-tailed Pearson correlation.

\section{Data Gathering Procedure}

A total of five hundred questionnaires were distributed personally to the Obafemi Awolowo University (OAU) Ife students. The questionnaires were numbered from 1-500 before distributing them. Students were not expected to indicate their names. It was to be anonymous; this was to ensure that students can react positively and faithfully to the items. The questionnaires were distributed to the study participants during their lectures after having taking officials permission from their course lecturers. The completed questionnaires were retrieved back from the participant after a week, in all 432 questionnaires were collected back. It was the 432 that were analyzed using descriptive and inferential statistics. 


\section{Result $S$ and Discussions}

Table 1: Importance of the Social Media

\begin{tabular}{|c|c|c|c|c|c|c|c|}
\hline & $\begin{array}{c}\text { How } \\
\text { important } \\
\text { is on line } \\
\text { discussion } \\
\text { Forum? }\end{array}$ & $\begin{array}{c}\text { How } \\
\text { important } \\
\text { is face } \\
\text { book? }\end{array}$ & $\begin{array}{c}\text { How } \\
\text { important } \\
\text { are blogs? }\end{array}$ & $\begin{array}{c}\text { How } \\
\text { important } \\
\text { is twitter? }\end{array}$ & $\begin{array}{c}\text { How } \\
\text { important } \\
\text { is open } \\
\text { source? }\end{array}$ & $\begin{array}{c}\text { How } \\
\text { important } \\
\text { is } \\
\text { you-tube/ } \\
\text { flickers? }\end{array}$ & $\begin{array}{c}\text { How } \\
\text { important } \\
\text { are smart } \\
\text { phones? }\end{array}$ \\
\hline $\mathrm{N}$ & 432 & 432 & 432 & 432 & 432 & 432 & 432 \\
\hline Mode & 3.00 & 3.00 & 3.00 & 2.00 & 3.00 & 2.00 & 3.00 \\
\hline Standard Deviation & .7252 & .7245 & .7601 & 1.2602 & .9552 & .8092 & .7335 \\
\hline Variance & .626 & .625 & .678 & 1.588 & .912 & .666 & .638 \\
\hline
\end{tabular}

From the above, face book was ranked the most important of the social media ( $\mathrm{SD}=0.7245$ ). This was followed by online discussion forum with standard deviation of 0.7252, smart phones, blogs and open source. While twitter and flickers were perceieved to be of less importance. Out of the two less important social media, you-tube was favoured over twitter. The student's choice may be attributed to cultural factors and ease of use.

Table 2: Frequency of Use of the Social Interactive Technologies in Education

\begin{tabular}{lccccccc}
\hline & Twitter & $\begin{array}{c}\text { Chart } \\
\text { room }\end{array}$ & $\begin{array}{c}\text { Internet } \\
\text { forum }\end{array}$ & Email/IM & Open-social & $\begin{array}{c}\text { Photo- } \\
\text { sharing site }\end{array}$ & $\begin{array}{c}\text { Music- sharing } \\
\text { site }\end{array}$ \\
\hline $\mathrm{N}$ & 432 & 432 & 432 & 432 & 432 & 432 & 432 \\
Mode & 3.00 & 2.00 & 2.00 & 1.00 & 2.00 & 1.00 & 2.00 \\
$\begin{array}{l}\text { StandardD } \\
\text { eviation }\end{array}$ & 0.8337 & 0.7913 & 0.7477 & 0.8160 & 0.7398 & 0.7698 & 0.8144 \\
Variance & 0.695 & 0.626 & 0.669 & 0.619 & 0.647 & 0.677 & 0.663 \\
\hline
\end{tabular}

Of all the social interactive media, E-mail and Instant Mailing (IM) are the most frequently used while those that are seldomly being used are micro-blogging (twitter), e-discussion (chart room). It was also revealed that the students regularly use the music- sharing site (0.8144).

Table 3: Perceived Usefulness of the Different Categories of Social Media

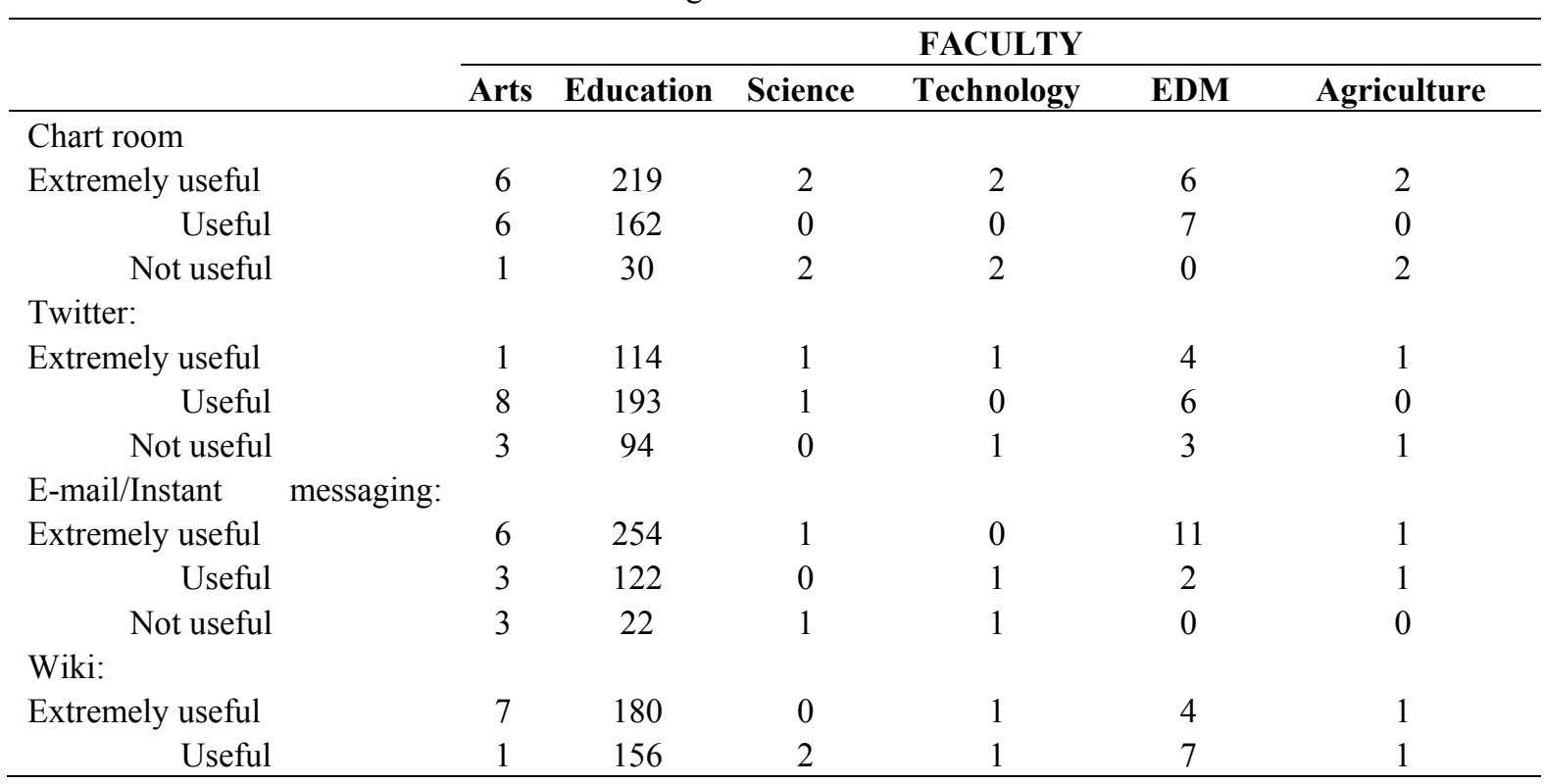




\begin{tabular}{ccccccc}
\hline Not useful & 4 & 65 & 0 & 0 & 2 & 0 \\
Photo-sharing/music sites & & & & & & \\
Extremely useful & 5 & 124 & 0 & 1 & 7 & 1 \\
Useful & 5 & 193 & 1 & 1 & 6 & 1 \\
Not useful & 2 & 84 & 1 & 0 & 1 & 0 \\
\hline
\end{tabular}

* Key $\quad$ EU $=$ extremely useful

US $=$ Useful

$\mathrm{NU}=$ Not useful

EDM=Enviromental Design and Management Faculty

The response of the sample across the six faculties showed that education students see the interactive social media as more useful to them. For Wiki 180 of the participants see it as extremely useful and 156 useful. On the other hand, 124 of the participants considered photo/music sharing- sites as extremely useful. The same trend ws recorded for E-mail and instant messaging (253 extremely useful and 126 useful). With regards to the possible factors responsible for the above, find the results in Table 4.

Table 4: Reasons for Utilization by the Students

\begin{tabular}{lccccccccc}
\hline & $\begin{array}{c}\text { For } \\
\text { comm-unication }\end{array}$ & $\begin{array}{c}\text { To } \\
\text { decongest } \\
\text { large } \\
\text { class }\end{array}$ & $\begin{array}{c}\text { value/social } \\
\text { class }\end{array}$ & $\begin{array}{c}\text { To improve } \\
\text { performance }\end{array}$ & $\begin{array}{c}\text { No } \\
\text { reason }\end{array}$ & $\begin{array}{c}\text { Easy } \\
\text { of } \\
\text { usage }\end{array}$ & $\begin{array}{c}\text { Self-paced } \\
\text { learning }\end{array}$ & Interactive & Flexible \\
\hline $\mathrm{N}$ & 432 & 432 & 432 & 432 & 432 & 432 & 432 & 432 & 432 \\
Mode & 1.00 & 1.00 & 4.00 & 2.00 & 4.00 & 1.00 & 2.00 & 1.00 & 1.00 \\
Standard & 0.601 & 0.606 & 1.165 & 0.849 & 1.119 & 0.617 & 0.675 & 1.670 & 0.7161 \\
deviation & 0.361 & 0.367 & 1.367 & 0.72 & 1.253 & 0.380 & 0.465 & 2.788 & 0.613 \\
Variance & 0.367 & & & & & & & & \\
\hline
\end{tabular}

The factors that motivated the use of the social interactive media across the six faculties include communication (0.361) followed by ability of the technology to decongest classroom (0.367), easy of usage (0.380), clarity/motivating (0.465) and lastly its flexible nature (0.613). Other perceived benefits of the social interactive media in the classroom as gathered from the data analyzed include its ability to enhance effective and efficient instruction in the classroom, social class recognition and value (See Table4)

On the effectiveness of social media as a tool in the classroom, find the response of the students across the different level.

Table 5: Effectiveness of Social Interactive Media as Innovative Instructional Tool in the Classroom

\begin{tabular}{lccccccc}
\hline & Part I & Part II & Part III & Part IV & Part V & PG & TOTAL \\
\hline Very effective & - & 290 & 7 & 20 & 0 & 3 & 320 \\
Effective & - & 91 & 4 & 9 & 0 & 1 & 105 \\
Ineffective & - & 2 & 1 & 1 & 1 & - & 5 \\
Very ineffective & - & - & 2 & - & - & - & 02 \\
Total & - & 383 & 14 & 30 & 1 & 4 & 432 \\
\hline
\end{tabular}

From the findings, it appears that only students in the second year level $(89 \%)$ adjudged that the social interactive media are effective in the classroom.

\section{Conclusions}

The four hypotheses were rejected as evidence from the findings revealed. With respect to hypothesis one, findings showed that there was a remarkable difference in their level of perceieved importance, hence the hypothesis was rejected.With respect to the extent of utilization, the findings also showed that there was difference in the frequency of utilization(see Table 2), also hypothesis two was rejected. On the perceived usefulness of the popular interactive media, data collected revealed that there was a remarkable difference in their level of usefulness.Education students perceived it more useful not only this the usefulness of each of the social media vary(see Tables $3 \& 4$ ), hence the third 
hypothesis was also rejected In summary, it was observed that the popular social interactive media was very effective in education and in the classroom. This was attested to by the data collected on the factors that affected their choice and perceived usefulness (See Table4\&5)

Based on the findings, the following conclusions are drawn. Social interactive technologies have penetrated not only higher education but secondary education in this $21^{\text {st }}$ century and more particularly during this era of economic recession. Its potentials and effectiveness are seen in the area of communication, enhancing teaching and learning, its ability to effectively decongest large class enrolment, academic publishing, collaboration, information management and knowledge-sharing. Other perceived benefits include flexibility, mobility of students and enhanced communication with instructors/lecturers in-and after classes and the innovative ways of presenting subject matters. Succinctly put, it can be concluded that social interactive technologies are effective in changing the image of schools, hence its effectiveness in the classroom to enhance flexible, creative and interactive learning.

\section{References}

Cohen, D. (1996). Standard based school reform: Policy, practice and performance. In H.F. Ladd (Ed)Holding school accountable performance-based school reform in education, Washington D.C. Brookling Institution.

Donnelly, R., \& Mesweency, F. (Eds) (2008). Applied e-learning and e-teaching in Higher Education. Wesley Information Science Reference. http://dx.doi.org/10.4018/978-1-59904-814-7

Donohue, B., \& Howe-Steiger, L. (2005). Faculty and Administrators Collaborating for E-Learning Course ware. Educause Quarterly, 28(1), 20-32.

Federal Government of Nigeria (2006).Milennium Development Goals on Education. FMI, Abuja.

Ferdig, R.E. (2008). Handbook of Research on electronic gaming in education. Hershey, Information Science Reference. http://dx.doi.org/10.4018/978-1-59904-808-6

Guilmette, C. (2011). Interactive classroom technology increasing student participation. Retrieved from the internet. On June11, 2011@ “The Lecture Tools Blog”.

Guri-Rosenblit, S. (2007). Higher Education in the $21^{\text {st }}$ Century: Seven Pairs of contrasting Trends. In J. Enders and P. Van-Vught [Eds] Towards a Cartography of Higher Education. Higher Education Policy, 18, 5-19. http://dx.doi.org/10.1057/palgrave.hep.8300069

Guri-Rosenblit, S. (2010). Digital technologies in Higher education: Sweeping expectations and actual effects. New York, Nova Science Publishers, Inc.

Immense Education (2008). Retrieved from the internet on June11, $2011 @$ http://immersive education.org

Lystras, M.D. Gasevic, D. Pables \& Hung, W. (2008). Technology enhanced learning: Best Practices. Hersey, PA: IGI Publishing. http://dx.doi.org/10.4018/978-1-59904-600-6

Machielse, C. (2011). Social media increases student-Teacher interaction and credibility.

Presidents' Committee of Advisers on Science and Technology. Report of the president on the use of technology to strengthen K-12 education in USA. Washington retrieved from the internet on june11, 2011 @ http://www.whitehouse.gov

This Day Newspaper (2006). Challenges of University Education in Nigeria. Editorial Comment: This Day Newspaper $19^{\text {th }}$ April 2006.

Walsh, K. (2010). Facebook as an instructional technology tool. Retrieved from the internet on June11, 2011@ The lecture Tool Blog.

Zeemsky, R., \& Massey, W.F. (2004a). Thwarted innovation: What happened to e-learning and why. University of Pennsylvania incorporation with Thompos Corporation University of Pennsylvania.

Zohar, A. (2010). Pedagogical horizons for learning. Paper presented during the 2011 Mashav training programme. State of Israel Ministry of Foreign Affairs. 